UCHOA, Adelaide Maria Rodrigues; RODRIGUES, Francisco Luciano Lima. Alienação de bens imóveis públicos em favor de particulares à luz dos princípios constitucionais da eficiência e economicidade. Revista Eletrônica Direito e Política, Programa de Pós-Graduação Stricto Sensu em Ciência Jurídica da UNIVALI, Itajaí, v.11, n.3, 30 quadrimestre de 2016. Disponível em: www.univali.br/direitoepolitica - ISSN 1980-7791.

\title{
ALIENAÇÃO GRATUITA DE BENS IMÓVEIS PÚBLICOS EM FAVOR DE PARTICULARES À LUZ DOS PRINCÍPIOS CONSTITUCIONAIS DA EFICIÊNCIA E DA ECONOMICIDADE
}

\author{
FREE DISPOSAL OF PUBLIC PROPERTY IN FAVOUR OF INDIVIDUALS: ANALYSIS \\ OF CONSTITUTIONAL PRINCIPLES OF EFFICIENCY AND ECONOMY
}

\section{Adelaide Maria Rodrigues Lopes Uchoa ${ }^{1}$ \\ Francisco Luciano Lima Rodrigues ${ }^{2}$}

SUMÁRIO: Introdução; 1. O Administrador Público e a alienação dos bens públicos; 2. Princípio constitucional da eficiência na Administração Pública e princípio da economicidade; 3. Análise do custo-benefício na alocação dos investimentos públicos relativos aos bens imóveis; Considerações finais; Referências das fontes citadas.

\section{RESUMO}

Os bens públicos podem ser utilizados pelo particular por meio de autorização, permissão, concessão de uso, concessão de direito real de uso e concessão de uso especial para fins de moradia, estes dois últimos destinados à exploração de atividades econômicas e a regularização fundiária de terrenos públicos indevidamente ocupados por particulares. A doação bens públicos encontra limitação no art. 17 da Lei 8.666/93, sendo possível a alienação onerosa para determinados fins sociais após o bem ser desafetado, precedida de avaliação prévia e mediante autorização legal. Cabe ao gestor, pautado também no princípio constitucional da eficiência, averiguar a relação custo-benefício na doação dos imóveis públicos, avaliando a economicidade do ato e a eficiência da medida ao tempo em se procede a análise jurídica do caso concreto. Os tribunais

\footnotetext{
${ }^{1}$ Graduada em Direito pela Universidade Federal do Ceará, Mestre em Direito Constitucional pela Universidade de Fortaleza e Doutora em Direito Constitucional pelo Programa Pós-Graduação em Direito Constitucional - Mestrado e Doutorado - da Universidade de Fortaleza- UNIFOR. Professora da Universidade de Fortaleza, em Fortaleza-Ceará. Procuradora do Município de Caucaia-Ceará. Endereço eletrônico: adelaideuchoa@hotmail.com

${ }^{2}$ Graduado em Direito pela Universidade de Fortaleza, Mestre em Direito (Direito e Desenvolvimento) pela Universidade Federal do Ceará e Doutor em Direito pela Universidade Federal de Pernambuco (2003). Realizou estágio de pesquisa na Faculdade de Direito da Universidade de Lisboa-Portugal (bolsista PDDE -CAPES). Professor Titular do Programa de PósGraduação em Direito Constitucional - Mestrado e Doutorado - da Universidade de FortalezaUNIFOR. Professor Adjunto da Faculdade de Direito da Universidade Federal do Ceará. ExCoordenador da Escola Superior da Magistratura do Estado do Ceará. Juiz de Direito - Membro Efetivo do Tribunal Regional Eleitoral do Ceará (2009-2012) Juiz de Direito -Titular da $8^{a}$ Vara da Fazenda Pública. Atualmente exerce a função de Juiz Auxiliar da Presidência do Tribunal de Justiça do Estado do Ceará. Endereço eletrônico: lucianolima@unifor.br
} 
UCHOA, Adelaide Maria Rodrigues; RODRIGUES, Francisco Luciano Lima. Alienação de bens imóveis públicos em favor de particulares à luz dos princípios constitucionais da eficiência e economicidade. Revista Eletrônica Direito e Política, Programa de Pós-Graduação Stricto Sensu em Ciência Jurídica da UNIVALI, Itajaí, v.11, n.3, 30 quadrimestre de 2016. Disponível em: www.univali.br/direitoepolitica - ISSN 1980-7791.

de contas vem admitindo a doação de imóveis em caráter excepcional, e vinculados a projetos habitacionais, todavia sugerem a utilização de concessões reais em lugar da doação, consideradas mais vantajosas para o patrimônio público.

Palavras-chave: Propriedade. Bens Públicos. Alienação. Eficiência. Economicidade.

\section{ABSTRACT}

Public properties can be used by the individual through an authorization, permit, license to use, granting right of use and granting of special use for housing purposes, for the exploitation of economic activities and the regularization of public land invaded. The disposal of public real state is limitation in article 17 of Law 8.666/93, it is possible for certain social ends, giving costly, after well be unaffected, preceded by assessment prior legal authorization. Public manager, also based on the constitutional principle of efficiency, shall determine the costbenefit ratio in the donation of public property, assessing the economy and efficiency of the act as to the time when it comes to legal analysis of the case. Courts of auditors has been accepting donations of property in an exceptional and linked to housing projects however suggest using real concessions instead of donation, considered more advantageous to the public patrimony.

Keywords: Property. Public Real Estate. Disposal. Efficiency. Economy.

\section{INTRODUÇÃO}

A administração de bens públicos exige do gestor uma conduta diferenciada. Se de um lado a Administração Pública não é propriamente a titular dos bens e interesses públicos, já que pertencem ao Estado, a ela compete administrar e por eles zelar de acordo com as finalidades a que estão adstritos, calcada no princípio da indisponibilidade dos bens públicos e seus pressupostos da inalienabilidade, imprescritibilidade e impenhorabilidade.

Ao tratar das alienações gratuitas de bens públicos aborda-se a qualidade das decisões que levam os gestores públicos a doarem imóveis em favor de particulares como também a interpretação que os Tribunais de Contas têm dado ao artigo 17 da Lei 8.666/93, a partir da edição da Lei de Regularização Fundiária. Busca-se ponderar também em que medida as decisões dos gestores 
UCHOA, Adelaide Maria Rodrigues; RODRIGUES, Francisco Luciano Lima. Alienação de bens imóveis públicos em favor de particulares à luz dos princípios constitucionais da eficiência e economicidade. Revista Eletrônica Direito e Política, Programa de Pós-Graduação Stricto Sensu em Ciência Jurídica da UNIVALI, Itajaí, v.11, n.3, 30 quadrimestre de 2016. Disponível em: www.univali.br/direitoepolitica - ISSN 1980-7791.

públicos na administração e disposição de bens imóveis públicos são considerados eficientes.

Tangenciando os Princípios Constitucionais que norteiam a atividade da Administração Pública, especialmente o princípio da eficiência, neste trabalho tenciona-se pesquisar se tal preceito é observado nos atos de alienação gratuita dos bens públicos, além de examinar os posicionamentos dos Tribunais de Contas e do Poder Judiciário acerca das doações de bens públicos a partir de arestos referenciados constantemente na jurisprudência.

Metodologicamente a pesquisa se caracteriza quanto aos meios de investigação por ser do tipo bibliográfica e documental, haja vista terem sido realizadas consultas tanto às fontes legislativas, especialmente à Constituição Federal de 1988, à Lei no 8.666/1993 e legislações municipais diversas que dispõem acerca do processo de alienação de bens públicos, como também foram catalogadas fontes doutrinárias concernentes à matéria explorada e analisadas as recomendações das cortes que julgam as contas públicas quanto à mitigação ou não dos atos de doação de bens imóveis públicos em favor de particulares.

Segundo a utilização dos resultados, a pesquisa é pura, tendo como escopo a ampliação dos conhecimentos sobre os delineamentos da propriedade pública e da conduta do administrador, do qual se exige além da legalidade, atendimento ao princípio constitucional da eficiência na gestão dos bens públicos.

Quanto à abordagem, a pesquisa é qualitativa, porquanto visa ao aprofundamento do tema que envolve dois princípios constitucionais: eficiência e economicidade, haja vista que, além de referências bibliográficas, extraídas de estudos de doutrinadores administrativistas nacionais, são analisados os fundamentos de algumas decisões dos tribunais de contas dos municípios, assim como o posicionamento adotado pelo Judiciário na atualidade.

Quanto aos fins, a pesquisa é descritiva, posto que define as características da propriedade pública e estabelece quais condutas do gestor público denotam eficiência na utilização dos recursos públicos. 
UCHOA, Adelaide Maria Rodrigues; RODRIGUES, Francisco Luciano Lima. Alienação de bens imóveis públicos em favor de particulares à luz dos princípios constitucionais da eficiência e economicidade. Revista Eletrônica Direito e Política, Programa de Pós-Graduação Stricto Sensu em Ciência Jurídica da UNIVALI, Itajaí, v.11, n.3, 30 quadrimestre de 2016. Disponível em: www.univali.br/direitoepolitica - ISSN 1980-7791.

\section{O ADMINISTRADOR PÚBLICO E A ALIENAÇÃO DOS BENS PÚBLICOS}

Antes de avançar no tema, e para compreensão da atuação do administrador público face o patrimônio que sobre ele tem poder de gerência, necessário tecer breve explanação acerca da natureza jurídica dos bens públicos, ressaltando, de logo que o enfoque do presente trabalho é o bem público imóvel, cuja classificação a partir das funções que exercem perante a coletividade, é consignada no artigo 99 da Lei 10.406/2002 (Código Civil Brasileiro de 2002).

São bens públicos de uso comum do povo aqueles cuja utilização é disponibilizada a todos, gratuitamente ou mediante retribuição, a exemplo das ruas, praças e mares, dentre outros.

Já os bens públicos de uso especial, não estão acessíveis a todas as pessoas, isto porque estão afetados ao algum serviço público, ainda que indiretamente, como os prédios onde funcionam as sedes de administração ou por outros bens, móveis ou imóveis que se destinem a alguma atividade autorizada e fiscalizada pelo ente público, como os cemitérios e ambulâncias.

Por exclusão, os bens dominiais ou dominicais são os que não estão afetados ao serviço ou função pública nem estão disponíveis para utilização pela coletividade, a exemplo dos imóveis desocupados, adjudicados em face de dívidas fiscais, terras devolutas. Guardam, portanto certa similaridade com a propriedade do particular, muito embora adstritos às regras do regime jurídico do patrimônio público. São esses os bens passíveis de alienação segundo o regime jurídico do patrimônio público, em regra, mediante procedimento licitatório.

Por serem públicos, todos os bens assim classificados fazem jus a uma proteção especial, a exemplo do artigo 102 do Código Civil e dos artigos 183, § 30, e 191, parágrafo único, da Constituição de 1988, ao se vedar a aquisição de bens públicos por usucapião. Ressalte-se que a Administração Pública deverá preservar os preceitos da indisponibilidade do interesse público e da supremacia do interesse público sobre o privado. Assim sendo, a transferência de uso dos bens públicos a terceiros tem limitações e só é admitida em casos excepcionais, quando presente o interesse público na utilização privativa do mesmo. 
UCHOA, Adelaide Maria Rodrigues; RODRIGUES, Francisco Luciano Lima. Alienação de bens imóveis públicos em favor de particulares à luz dos princípios constitucionais da eficiência e economicidade. Revista Eletrônica Direito e Política, Programa de Pós-Graduação Stricto Sensu em Ciência Jurídica da UNIVALI, Itajaí, v.11, n.3, 30 quadrimestre de 2016. Disponível em: www.univali.br/direitoepolitica - ISSN 1980-7791.

Os institutos que servem para legitimar o uso privativo de bens públicos são: a) autorização de uso; b) permissão de uso; c) concessão de uso; d) concessão de direito real de uso; e) concessão de uso especial para fins de moradia. A autorização, a permissão e a concessão de uso transmitem apenas o direito de usar e explorar economicamente o bem público, não gerando direitos reais, tão somente obrigacionais. A concessão de direito real de uso e a concessão de uso especial para fins de moradia estão consignadas no artigo 1.225 do Código Civil, o qual elenca de modo taxativo as hipóteses legais de direitos reais.

A concessão de direito real de uso é instituto regulado pelo Decreto-lei no 271 , de 28/02/1967, consistindo em um contrato administrativo pelo qual o Poder Público confere ao particular direito real resolúvel de uso de terreno público ou espaço aéreo que o recobre, segundo as finalidades preestabelecidas de regularização fundiária de interesse social, urbanização, industrialização, edificação, cultivo da terra, aproveitamento sustentável das várzeas, preservação das comunidades tradicionais e seus meios de subsistência ou outras modalidades de interesse social em áreas urbanas. Segundo o aludido Decretolei no 271/67, a concessão deve ter como fim específico uma finalidade social e tal direito real é transmissível entre vivos ou por sucessão causa mortis.

Dado que os imóveis públicos não são passíveis de usucapião, foi projetado outro instrumento da Política Urbana que se assemelhasse ao instituto da usucapião especial de imóvel urbano (pro morare), a fim de implementar o direito de moradia: a Concessão de Uso Especial para fins de Moradia (CUEM), disciplinada atualmente pela Medida Provisória 2.220 de 04 de setembro de 2001, em face de veto presidencial ao artigos 10 a 15 da Lei no 10.257/2001 - Estatuto da Cidade. Esta modalidade de concessão é instrumento jurídico da Política Urbana, destinado à regularização fundiária dos terrenos públicos que estão sob a detenção de pessoas estranhas à administração pública, ou seja, regularizar a posse de terras invadidas. O intuito é, atentando-se para a reserva do possível, conferir efetividade ao direito de moradia, previsto no art. $6^{\circ}$ da Constituição da República. 
UCHOA, Adelaide Maria Rodrigues; RODRIGUES, Francisco Luciano Lima. Alienação de bens imóveis públicos em favor de particulares à luz dos princípios constitucionais da eficiência e economicidade. Revista Eletrônica Direito e Política, Programa de Pós-Graduação Stricto Sensu em Ciência Jurídica da UNIVALI, Itajaí, v.11, n.3, 30 quadrimestre de 2016. Disponível em: www.univali.br/direitoepolitica - ISSN 1980-7791.

A despeito dos caracteres da propriedade imobiliária pública, especialmente a inalienabilidade, a transmissão de bens constitui uma realidade cotidiana com as doações de bens imóveis públicos em favor de indústrias, associações privadas, igrejas, dentre outras, sem mencionar a conduta do gestor público que desfalca o patrimônio coletivo por meio de alienações gratuitas em favor de particulares, sob o pálio de pretenso interesse público e da discricionariedade do ato.

Diante dessas considerações, enfoca-se a alienação dos bens públicos sob a ótica jus-econômica, abordando também o papel do gestor público e dos tribunais que julgam as contas públicas.

Para tanto deve ser evidenciada a Lei no 8.666/93 (Lei de Licitações e Contratos Administrativos) que, ao regulamentar o artigo 37, XXI da Constituição da República, estabeleceu normas gerais sobre licitações e contratos administrativos pertinentes a obras, serviços, inclusive de publicidade, compras, alienações e locações no âmbito dos Poderes da União, dos Estados, do Distrito Federal e dos Municípios.

No inciso I do artigo 17 da Lei no 8.666/93, com nova redação conferida pelas leis de números 11.481/2007 e 11.952/2009, (leis de regularização fundiária), foram fixadas normas gerais que autorizam a doação de bens públicos imóveis em determinadas hipóteses, o que necessariamente deve ser observado pelos entes estatais, com base no artigo $24, \S \S 1^{\circ}, 2^{\circ}$ e $4^{\circ}$ da Constituição Federal de 1988.

A Lei no 8.666/93 (Lei de Licitações e Contratos Administrativos) permite a doação de bens imóveis públicos, excepcionalmente, em favor de particulares se cumpridas algumas formalidades: interesse público devidamente justificado, avaliação do imóvel, autorização legislativa, licitação na modalidade concorrência e doação modal (com encargos ou obrigações) e condicional resolutiva (com cláusula de reversão).

Assinale-se que a doação de bens públicos encontra limitação no art. 17 da referida lei. Em face do regime patrimonial que afeta os bens públicos, há certas 
UCHOA, Adelaide Maria Rodrigues; RODRIGUES, Francisco Luciano Lima. Alienação de bens imóveis públicos em favor de particulares à luz dos princípios constitucionais da eficiência e economicidade. Revista Eletrônica Direito e Política, Programa de Pós-Graduação Stricto Sensu em Ciência Jurídica da UNIVALI, Itajaí, v.11, n.3, 30 quadrimestre de 2016. Disponível em: www.univali.br/direitoepolitica - ISSN 1980-7791.

restrições quanto à livre disposição dos bens titularizados pela pessoa jurídica de direito público interno.

A autorização legislativa é exigência aplicada para fins de proteção ao patrimônio público dos órgãos da Administração Pública direta, entidades autárquicas e fundacionais, devendo tal ordem, quando deferida, ser específica para a alienação do bem imóvel descrito e seus limites geográficos, para tanto bastando que seja editada lei ordinária autorizativa, salvo expressa disposição em outro sentido.

A avaliação do bem imóvel deve ser realizada de maneira preliminar a fim de quantificar, com precisão e de forma atualizada, o patrimônio estatal a ser alienado, e assim auxiliar na tomada de decisão pelo imóvel mais adequado. Lúcia Valle Figueiredo assinala que a "alienação somente poderá ser procedida, mesmo com lei e licitação, se presentes razões de interesse público devidamente explicitadas (portanto, motivação é indispensável) que conduzam à alienação"³.

A realização da licitação para alienação de bens imóveis é dispensada nos casos relacionados no inciso I, alíneas "a" até " $\mathrm{h}$ "4, o que inclui a hipótese de doação,

${ }^{3}$ FIGUEIREDO, Lúcia Valle. Curso de direito administrativo. 7.ed. São Paulo: Malheiros, 2004. p. 566.

${ }^{4}$ Art. 17. A alienação de bens da Administração Pública, subordinada à existência de interesse público devidamente justificado, será precedida de avaliação e obedecerá às seguintes normas: I - quando imóveis, dependerá de autorização legislativa para órgãos da administração direta e entidades autárquicas e fundacionais, e, para todos, inclusive as entidades paraestatais, dependerá de avaliação prévia e de licitação na modalidade de concorrência, dispensada esta nos seguintes casos: a) dação em pagamento; b) doação, permitida exclusivamente para outro órgão ou entidade da administração pública, de qualquer esfera de governo, ressalvado o disposto nas alíneas f e h; (Incluído pela Lei no 11.952, de 25 de junho de 2009) c) permuta, por outro imóvel que atenda aos requisitos constantes do inciso $X$ do art. 24 desta Lei; d) investidura; e) venda a outro órgão ou entidade da administração pública, de qualquer esfera de governo; (Incluído pela Lei no 8.883, de 8.6.94) f) alienação gratuita ou onerosa, aforamento, concessão de direito real de uso, locação ou permissão de uso de bens imóveis residenciais construídos, destinados ou efetivamente utilizados no âmbito de programas habitacionais ou de regularização fundiária de interesse social desenvolvidos por órgãos ou entidades da administração pública; (Redação dada pela Lei no 11.952, de 25 de junho de 2009) g) [...] h) alienação gratuita ou onerosa, aforamento, concessão de direito real de uso, locação ou permissão de uso de bens imóveis de uso comercial de âmbito local com área de até $250 \mathrm{~m}^{2}$ (duzentos e cinqüenta metros quadrados) e inseridos no âmbito de programas de regularização fundiária de interesse social desenvolvidos por órgãos ou entidades da administração pública; (Incluído pela Lei no 11.952, de 25 de junho de 2009) (...) § 10 Os imóveis doados com base na alínea "b" do inciso I deste artigo, cessadas as razões que justificaram a sua doação, reverterão ao patrimônio da pessoa jurídica doadora, vedada a sua alienação pelo beneficiário. § $20 \mathrm{~A}$ Administração poderá conceder direito real de uso de bens imóveis, dispensada licitação, quando o uso se destina a outro órgão ou entidade da Administração Pública. 
UCHOA, Adelaide Maria Rodrigues; RODRIGUES, Francisco Luciano Lima. Alienação de bens imóveis públicos em favor de particulares à luz dos princípios constitucionais da eficiência e economicidade. Revista Eletrônica Direito e Política, Programa de Pós-Graduação Stricto Sensu em Ciência Jurídica da UNIVALI, Itajaí, v.11, n.3, 30 quadrimestre de 2016. Disponível em: www.univali.br/direitoepolitica - ISSN 1980-7791.

que é uma das espécies de alienação previstas nesta lei, e que, no caso da União, é exclusivamente permitida para órgão ou entidade de sua Administração Pública, com exceção das hipóteses prescritas nas alíneas "f" e " $h$ ".

Ressalte-se que a $2^{a}$ parte do disposto no art. 17, inciso I, alínea "b" - "permitida exclusivamente para órgão ou entidade da Administração Pública" - está com sua eficácia suspensa até decisão final, em relação aos Estados, Distrito Federal e Municípios, em face da liminar concedida em 1994, na Ação Direta de Inconstitucionalidade no 927-3, interposta pelo Governador do Estado do Rio Grande Sul, ainda em tramitação no Supremo Tribunal Federal.

A regra geral, após decisão do STF e as alterações legais citadas, orienta que a doação bens imóveis do patrimônio público pertencente ao município pressupõe que haja interesse público devidamente justificado; o bem seja desafetado, se for caso; seja precedida de avaliação prévia; seja conferida autorização por lei; inexista obrigatoriedade de realizar certame licitatório, de fazê-lo exclusivamente para órgão ou entidade da Administração Pública de qualquer esfera do governo, e de constar no instrumento dessa doação, as cláusulas de inalienabilidade e reversão ao patrimônio público do bem imóvel doado.

Assim, como consequência da ADI 927-3, frisa-se que a União pode doar bem público imóvel apenas para outro órgão ou entidade da Administração Pública, de qualquer esfera do governo, salvo nos casos previstos nas alíneas "f" e " $h$ ", inciso I do art. 17 da Lei no 8.666/93.

O Município, por sua vez, fazendo uso de sua autonomia administrativa pode normatizar regras sobre alienações, desde que respeitadas aquelas gerais prescritas na Lei no 8.666/93 e os dispositivos da Constituição Federal, que, entre outros, consagra os princípios da isonomia e da impessoalidade (arts. 50, caput e 37, caput, ambos da CF/88).

Examinado o conteúdo das alíneas "f" e " $h$ " do inciso I do artigo 17, deve ser assinalado que as exceções ali contidas voltam-se, prioritariamente, a 
UCHOA, Adelaide Maria Rodrigues; RODRIGUES, Francisco Luciano Lima. Alienação de bens imóveis públicos em favor de particulares à luz dos princípios constitucionais da eficiência e economicidade. Revista Eletrônica Direito e Política, Programa de Pós-Graduação Stricto Sensu em Ciência Jurídica da UNIVALI, Itajaí, v.11, n.3, 30 quadrimestre de 2016. Disponível em: www.univali.br/direitoepolitica - ISSN 1980-7791.

implementação de políticas públicas habitacionais e de empreendedorismo, todavia, procuram resguardar o patrimônio público imobiliário. Vale esclarecer que a concessão de uso ou a concessão de direito real de uso (CDRU), embora com semelhantes nomenclaturas, são institutos que não se confundem, mormente por ser, esta última, a CDRU, um direito real e somente efetivado em caso de interesse social.

Essas modalidades também não se confundem com a cessão de uso transferência gratuita de posse de um bem público entre entidades ou órgãos públicos - consistindo em utilização temporária.

A concessão do direito real de uso (CDRU) foi introduzida na ordem jurídica vigente pelo Decreto-Lei no 271/67, com a finalidade de substituir a doação de terrenos públicos a pessoas hipossuficientes, para o que se submetia o particular a um procedimento simples, que dispensava inclusive escritura pública, assegurando-se que além de usar como se dono fosse, o concessionário poderia utilizar esse título (contrato) como garantia de financiamento para a edificação ${ }^{5}$.

$\mathrm{Na}$ época em que se iniciou a vigência do Decreto 271/1967, esse tipo de concessão de direito real de uso não foi exitoso na prática; não obstante, com a vigência do Estatuto da Cidade conferiu-se mais robustez ao instituto, alçando-o à categoria de instrumento da Política Urbana e o inserindo no rol de direitos reais do artigo 1.225 do Código Civil de 2002, o que propiciou a operacionalização do instituto.

Meirelles constata o desvirtuamento das outorgas de bens públicos e aponta que a cessão em favor de órgão público da mesma entidade, que, não se confunde com as demais modalidades de outorga da posse de bem público em favor de particular (autorização, permissão e concessão de uso), por assegurar que o bem continuará a servir à gestão pública, vem sendo substituída pela doação, por vezes em favor de particulares ${ }^{6}$.

\footnotetext{
${ }^{5}$ MEIRELLES, Hely Lopes. Direito de construir. 9. ed. atual. São Paulo: Malheiros, 2005, p. 163.

${ }^{6}$ MEIRELLES, Hely Lopes. Direito Administrativo Brasileiro. 21. ed. São Paulo: Malheiros, 1996, p. 435.
} 
UCHOA, Adelaide Maria Rodrigues; RODRIGUES, Francisco Luciano Lima. Alienação de bens imóveis públicos em favor de particulares à luz dos princípios constitucionais da eficiência e economicidade. Revista Eletrônica Direito e Política, Programa de Pós-Graduação Stricto Sensu em Ciência Jurídica da UNIVALI, Itajaí, v.11, n.3, 30 quadrimestre de 2016. Disponível em: www.univali.br/direitoepolitica - ISSN 1980-7791.

Em se tratando de cessão de bem público para outra entidade igualmente pública, além de lei autorizativa para a transmissão da posse do bem, necessária se faz a formalização da cessão por ato administrativo próprio. Contudo, é dispensada a licitação nos termos do $2^{\circ}$ do artigo 17 da Lei no 8.666/93, já que o bem será destinado atividade uma de interesse público ${ }^{7}$.

Carvalho Filho aponta que a utilização da concessão de direito real de uso (CDRU) tem como vantagem salvaguardar o patrimônio público e evitar a alienação de bens que não traga proveito, além de exigir do concessionário que respeite a destinação para a qual foi o bem concedido. Nesse aspecto, pode a CDRU voltar-se ao incentivo de edificações ou ao desenvolvimento de relevante atividade econômica para o Estado ou Município em determinado espaço ${ }^{8}$.

Ademais, a concessão de uso e a concessão de direito real de uso não são instrumentos precários, permitem revogação unilateral por interesse público, porém resguardam o direito à indenização pelas benfeitorias e construções ao solo aderidas.

Regulamentando o $\S 1^{0}$ do art. 183 da Magna Carta, a Medida Provisória no 2.220, de 04 de setembro de 2001, definiu requisitos para possibilitar essa regularização fundiária, com a preocupação de coibir "invasões" de terrenos públicos $^{9}$. A concessão de uso especial para fins de moradia (CUEM) ali prevista possui como pressupostos: posse ininterrupta e sem oposição por cinco anos até 30 de junho de 2001; imóvel urbano público de até $250 \mathrm{~m}^{2}$ (duzentos e cinquenta metros quadrados); uso do terreno para fins de moradia do possuidor ou de sua família; não ter o possuidor a propriedade de outro imóvel urbano ou

\footnotetext{
7 CARVAlHO Filho, José dos Santos. Manual de direito administrativo. 23. ed. rev., ampl. e atual., 2a tiragem, Rio de Janeiro: Lúmen Júris, 2010, p. 1.283.

${ }^{8}$ CARVALHO FILHO, José dos Santos. Manual de direito administrativo. p. 1.282.

${ }^{9}$ BRASIL. Medida Provisória no 2.220, de 4 de setembro de 2001. Dispõe sobre a concessão de uso especial de que trata $\circ \S 1^{\circ}$ do art. 183 da Constituição, cria o Conselho Nacional de Desenvolvimento Urbano - CNDU e dá outras providências. Disponível em: <http://www.planalto.gov.br/ccivil_03/mpv/2220.htm>. Acesso em: 06 jan. 2016. "Art. 10 Aquele que, até 30 de junho de 2001, possuiu como seu, por cinco anos, ininterruptamente e sem oposição, até duzentos e cinqüenta metros quadrados de imóvel público situado em área urbana, utilizando-o para sua moradia ou de sua família, tem o direito à concessão de uso especial para fins de moradia em relação ao bem objeto da posse, desde que não seja proprietário ou concessionário, a qualquer título, de outro imóvel urbano ou rural.
} 
UCHOA, Adelaide Maria Rodrigues; RODRIGUES, Francisco Luciano Lima. Alienação de bens imóveis públicos em favor de particulares à luz dos princípios constitucionais da eficiência e economicidade. Revista Eletrônica Direito e Política, Programa de Pós-Graduação Stricto Sensu em Ciência Jurídica da UNIVALI, Itajaí, v.11, n.3, 30 quadrimestre de 2016. Disponível em: www.univali.br/direitoepolitica - ISSN 1980-7791.

rural; não ter o possuidor obtido anteriormente concessão de uso para fins de moradia.

Não obstante as concessões e doações de bens públicos serem limitadas pela Lei 8.666/93, restringindo-se às exceções traduzidas no interesse público, a prática de concessão de incentivos para implementação de atividades econômicas de natureza privada é uma constante na realidade dos municípios brasileiros, que arguindo a autonomia do ente local, por lei municipal, incluem outras hipóteses de alienabilidade dos bens públicos, algumas francamente contrárias à lei 8.666/93, sob a rubrica de incentivos ao desenvolvimento das potencialidades econômicas do município.

A legislação infraconstitucional enseja ao Poder Público conceder incentivos econômicos à entidades privadas de fins lucrativos das mais diversas ordens, no intuito de facilitar a instalação de empresas e indústrias no município, e proporcionar incremento na economia local.

A política voltada para a geração de "emprego e renda" acaba sendo o fundamento dos incentivos fiscais e econômicos concedidos aos particulares, que tanto podem versar sobre diminuição patrimonial como também de renúncias temporárias de receitas públicas, contrariando o preceito da indisponibilidade dos bens públicos.

Os artigos 12 a 21 da Lei no 4.320/64, embora de aplicação restrita, abrem uma possibilidade para a Administração Pública conceder incentivos econômicos em favor de empresas privadas de fins lucrativos; o artigo 70 do Decreto-lei no 271/67 prevê que, para fins de industrialização, mediante certas condições, pode o ente público conceder o uso de terrenos públicos para particulares, gratuita ou remuneradamente; o Código Tributário Nacional, nos artigos 176 e 179, dispõe sobre a possibilidade da isenção de tributos. Por fim, vale ainda ressaltar que o artigo 17, I, " $h$ " da lei de Licitações e Contratos Administrativos permite alienação de bens nos termos ali elencados.

A concessão de incentivos econômicos às empresas privadas de fins lucrativos, para se instalarem no território de uma unidade federativa, só é possível 
UCHOA, Adelaide Maria Rodrigues; RODRIGUES, Francisco Luciano Lima. Alienação de bens imóveis públicos em favor de particulares à luz dos princípios constitucionais da eficiência e economicidade. Revista Eletrônica Direito e Política, Programa de Pós-Graduação Stricto Sensu em Ciência Jurídica da UNIVALI, Itajaí, v.11, n.3, 30 quadrimestre de 2016. Disponível em: www.univali.br/direitoepolitica - ISSN 1980-7791.

respeitando-se os princípios que regem a Administração Pública, cumprindo-se os requisitos previstos pela legislação e atendendo-se o interesse público, sob pena de invalidade do ato e responsabilização do agente público. As despesas realizadas pelo Poder Público com incentivo à empresas privadas de fins lucrativos e as isenções fiscais a elas concedidas igualmente só poderão ocorrer se previstas na lei orçamentária votada no exercício anterior. Tudo isso por uma questão de planejamento e execução do orçamento dentro do possível para aquele ente público.

De modo geral, a doação de bens públicos, para ser lícita, necessita de prévia autorização legislativa, avaliação, procedimento licitatório e atendimento do interesse público.

Com fundamento nas limitações consignadas pela Lei de Licitações e Contratos Administrativos, depreende-se que a alienação não onerosa dos bens públicos reclama do gestor público mais do que o comprometimento com o interesse coletivo, pressupõe estrita observância aos princípios da administração pública, de modo que realize os investimentos públicos o mais eficientemente possível.

\section{PRINCÍPIO CONSTITUCIONAL DA EFICIÊNCIA NA ADMINISTRAÇÃO PÚBLICA E PRINCÍPIO DA ECONOMICIDADE}

A Emenda Constitucional no 19 de 04 de junho de 1998, alterou o artigo 37 da Constituição de 1988, e nele acrescentou o Princípio da Eficiência, que passou a figurar ao lado dos demais princípios que regem a Administração Pública: os princípios da legalidade, impessoalidade, moralidade e publicidade.

Eficiência refere-se ao modo de fazer algo; à aptidão de obter os melhores resultados possíveis, dentro de um determinado meio, com os recursos disponibilizados e no menor tempo possível. Todavia delinear a eficiência exigida da Administração Pública é tarefa demasiado árdua, especialmente se descontextualizado. 
UCHOA, Adelaide Maria Rodrigues; RODRIGUES, Francisco Luciano Lima. Alienação de bens imóveis públicos em favor de particulares à luz dos princípios constitucionais da eficiência e economicidade. Revista Eletrônica Direito e Política, Programa de Pós-Graduação Stricto Sensu em Ciência Jurídica da UNIVALI, Itajaí, v.11, n.3, 30 quadrimestre de 2016. Disponível em: www.univali.br/direitoepolitica - ISSN 1980-7791.

Não se pode exigir que a eficiência administrativa seja o único aspecto a ser considerado nas decisões do administrador, mas ponderando-se a eficiência, sem afastar-se da legalidade, da moralidade e da publicidade, a decisão do gestor poderá resultar na melhor opção para o bem coletivo, fim último da administração pública. A partir daí, fundamental anotar ter sido o Princípio da Eficiência inserido no texto constitucional sob influxos neoliberais com o objetivo de que a gestão da coisa pública se tornasse menos burocrática, menos dispendiosa, que a atuação do administrador, assim como dos servidores fosse mais rápida, sem contudo, descurar da boa qualidade, a exemplo das práticas da iniciativa privada, do que diverge pela indisponibilidade dos bens e interesses públicos.

Oriundo da ciência da Administração, o princípio da eficiência deve ser considerado sob um duplo aspecto na ótica de Maria Sylvia Zanella Di Pietro: em relação ao modo de atuação do agente público, que, de acordo com as atribuições que Ihe são inerentes, deverá atuar da melhor forma possível de modo que alcance os resultados mais expressivos, e em relação à estrutura da da Administração Pública, cujo objetivo também é a obtenção dos melhores resultados na prestação do serviço público ${ }^{10}$.

A autora explicita também os objetivos que se pretendeu alcançar com a inclusão do princípio da eficiência na Emenda Constitucional no 19, em parte responsável pela chamada Reforma do Estado:

[...] reformar o Estado significa melhorar não apenas a organização e o pessoal do Estado, mas também as finanças e todo o seu sistema institucional-legal, de forma a permitir que o mesmo tenha uma relação harmoniosa e positiva com a sociedade civil. A reforma do Estado permitirá que seu núcleo estratégico tome decisões mais corretas e efetivas, e que seus serviços - tanto os exclusivos, quanto os competitivos, que estarão apenas indiretamente subordinados na medida que se transformem em organizações públicas não estatais - operem muito eficientemente ${ }^{11}$.

${ }^{10}$ DI PIETRO, Maria Sylvia Zanella. Direito administrativo. 25. ed. São Paulo: Atlas, 2012, p. 84.

${ }^{11}$ DI PIETRO, Maria Sylvia Zanella. Direito administrativo. p. 84. 
UCHOA, Adelaide Maria Rodrigues; RODRIGUES, Francisco Luciano Lima. Alienação de bens imóveis públicos em favor de particulares à luz dos princípios constitucionais da eficiência e economicidade. Revista Eletrônica Direito e Política, Programa de Pós-Graduação Stricto Sensu em Ciência Jurídica da UNIVALI, Itajaí, v.11, n.3, 30 quadrimestre de 2016. Disponível em: www.univali.br/direitoepolitica - ISSN 1980-7791.

Dessume-se que o princípio de eficiência revela um aspecto econômico, já que direciona os agentes e servidores públicos a buscarem os melhores resultados ao menor custo e utilizando os meios que dispõem.

Segundo Gilberto Bercovici, sob o influxo da Reforma do Estado que perdurou entre 1995 a 2002, a Emenda Constitucional no 19, tencionando melhorar a qualidade das decisões estratégicas do governo, buscou instituir o "Estado Gerencial", cuja "preocupação se dá em termos de eficiência e resultados, transplantando mecanismos da iniciativa privada para a Administração Pública e pautando a atuação do Estado pelo mercado"12.

Ressalte-se ainda que no pacote de medidas da Reforma do Estado, houve lugar também para a regulação das ações dos agentes públicos, a fim de que o serviço, assim como a administração dos bens públicos, pudessem ser otimizados.

Inspirando-se modelos da iniciativa privada, cujos resultados são visivelmente favoráveis, é que a tônica da eficiência constitucionalmente exigida consubstanciou-se no equilíbrio de alguns vetores: maximização dos resultados, redução dos custos e satisfação da sociedade, com a utilização dos meios de que se dispõe.

Hely Lopes Meireles assinala que a inserção do Princípio da Eficiência se traduz em reforço necessário aos demais princípios, visto que impõe ao agente público a realização das atribuições que Ihe são cometidas com presteza, perfeição e rendimento funcional. Afirma ainda ser o mais moderno princípio da função administrativa, que extrapola ao mero atendimento à legalidade e passa a exigir resultados vantajosos ao serviço público e suficiência no atendimento às necessidades dos administrados ${ }^{13}$.

Outrossim, identificando-se a eficiência com a máxima utilidade que se pode extrair de determinado recurso, não se pode olvidar que o administrador público,

\footnotetext{
12 BERCOVICI, Gilberto. Constituição econômica e desenvolvimento. Uma leitura a partir da Constituição de 1988. São Paulo: Malheiros, 2005, p. 82.

13 MEIRELLES, Hely Lopes. Direito Administrativo Brasileiro. p. 60.
} 
UCHOA, Adelaide Maria Rodrigues; RODRIGUES, Francisco Luciano Lima. Alienação de bens imóveis públicos em favor de particulares à luz dos princípios constitucionais da eficiência e economicidade. Revista Eletrônica Direito e Política, Programa de Pós-Graduação Stricto Sensu em Ciência Jurídica da UNIVALI, Itajaí, v.11, n.3, 30 quadrimestre de 2016. Disponível em: www.univali.br/direitoepolitica - ISSN 1980-7791.

responsável pela gestão dos bens públicos, dentro da moldura composta pelos princípios enunciados no artigo 37 da Constituição Federal de 1988, deverá conferir aos bens públicos uma exploração econômica compatível com a destinação do bem; de outro lado, cabe igualmente a ele decidir pela melhor forma de aproveitamento dos bens servíveis.

Deve ainda ser avaliada se a decisão do administrador público, quanto ao uso e à disposição do bem público, além de legalmente fundada, reflete a eficiência buscada no texto constitucional. Nesse sentido, cabe averiguar a relação custobenefício das medidas adotadas pelo gestor público no gerenciamento dos bens públicos, quando postos em xeque os recursos que não lhe pertencem, mas que, por serem públicos, devem priorizar as políticas públicas.

Assim, no processo de realização do direito, tanto na elaboração legislativa, quanto na aplicação e interpretação da norma, deverão ser levados em conta os impactos que podem incentivar ou desestimular determinada prática. $E$, portanto, nas relações que envolvam decisões, as externalidades merecem ser consideradas a fim de se aquilatarem os impactos sociais provocados por uma norma jurídica ou por uma decisão judicial ${ }^{14}$.

Esse raciocínio, baseado na avaliação prévia das consequências das medidas adotadas, poderá ser estendido às decisões da Administração Pública, quanto ao uso eficiente dos serviços e do dos bens públicos. A motivação do ato, corolário das decisões administrativas, deve transcender a legalidade no sentido garantir também a eficiência prestacional. Não é só motivar o ato, é também justificar que o ato é necessário, porque reflete a opção mais eficiente na concretização de um direito.

Marcus Juruena Villela Souto, complementando o raciocínio de Hely Lopes Meirelles, sinaliza que a eficiência não se limita a parâmetros de presteza, perfeição e rendimento; pelo menos, a eficiência que se perquire nos atos de

\footnotetext{
14 VENTURI, Thaís G. Pascoaloto. A análise consequencialista no processo de tomadas das decisões judiciais a partir da obra de Ricardo L. Lorenzetti. In: TEPEDINO, Gustavo; Fachin, Luiz Edson (Org.). Diálogos sobre direito civil. Rio de Janeiro: Renovar, 2012. v. III, p. 142.
} 
UCHOA, Adelaide Maria Rodrigues; RODRIGUES, Francisco Luciano Lima. Alienação de bens imóveis públicos em favor de particulares à luz dos princípios constitucionais da eficiência e economicidade. Revista Eletrônica Direito e Política, Programa de Pós-Graduação Stricto Sensu em Ciência Jurídica da UNIVALI, Itajaí, v.11, n.3, 30 quadrimestre de 2016. Disponível em: www.univali.br/direitoepolitica - ISSN 1980-7791.

Administração Pública. Afirma que essa eficiência pressupõe ação nos parâmetros da lei e voltada para a finalidade pública, acrescentando também o respeito aos valores e princípios que orientam o sistema jurídico e atendem aos interesses da sociedade. $E$, justifica a necessidade de eficiência econômica e eficiência social serem conjugadas para a obtenção da eficiência administrativa. Para ele, considera-se alcançada a eficiência quando o resultado da medida levou em conta todos os interesses envolvidos e pautou-se nos princípios acolhidos na ordem jurídica. Nessa valoração está, portanto a essência da atividade administrativa ${ }^{15}$.

Nesta senda, outro princípio exsurge ao lado do princípio da eficiência: o princípio que pressupõe a economicidade nos atos e decisões oriundas do poder público. A economicidade se vincula, no domínio das ciências econômicas e de gestão, à ideia fundamental de desempenho qualitativo. Trata-se da obtenção do melhor resultado estratégico possível de uma determinada alocação de recursos financeiros, econômicos e/ou patrimoniais em um dado cenário socioeconômico ${ }^{16}$.

O princípio da economicidade guarda estreita relação com o princípio da eficiência e norteia a boa gestão de recursos e a eficiente utilização dos bens públicos; e está previsto no art. 70 da Constituição Federal de 1988, o qual dispõe sobre as diversas formas de fiscalização que incidem sobre as atividades desempenhadas no âmbito da Administração Pública ${ }^{17}$.

Lúcia Valle Figueiredo afirma ter a economicidade conteúdo semântico, refletindo a relação entre custos e benefícios. E complementa: "Aliás, em qualquer forma de administração o binômio custo-benefício é observado. Haveria irrazoabilidade

${ }^{15}$ SOUTO, Marcos Juruena Villela. Direito administrativo em debate. $2^{a}$ série. Rio de Janeiro: Lúmen Júris, 2007, p. 37.

${ }^{16}$ BUGARIN, Paulo Soares. Reflexões sobre o princípio constitucional da economicidade e o papel do TCU. IN: Revista do Tribunal de Contas da União - R.TCU, Brasília, v. 29 , n. 78, out/dez 1998. Disponível em: <http://docplayer.com.br/8413952-Revista-do-tribunal-de-contasda-uniao.html>. Acesso em: 05 dez. 2015.

17 Art. 70 - A fiscalização contábil, financeira, orçamentária, operacional e patrimonial da União e das entidades da administração direta e indireta, quanto à legalidade, legitimidade, economicidade, aplicação das subvenções e renúncia de receitas, será exercida pelo Congresso Nacional, mediante controle externo, e pelo sistema de controle interno de cada Poder. 
UCHOA, Adelaide Maria Rodrigues; RODRIGUES, Francisco Luciano Lima. Alienação de bens imóveis públicos em favor de particulares à luz dos princípios constitucionais da eficiência e economicidade. Revista Eletrônica Direito e Política, Programa de Pós-Graduação Stricto Sensu em Ciência Jurídica da UNIVALI, Itajaí, v.11, n.3, 30 quadrimestre de 2016. Disponível em: www.univali.br/direitoepolitica - ISSN 1980-7791.

se o custo fosse desproporcional ao benefício. E, atualmente, a eficiência reforça a economicidade" ${ }^{18}$.

Ricardo Lobo Torres identifica o controle da economicidade com o controle da eficiência na gestão financeira e na execução orçamentária, consubstanciada na minimização de custos e gastos públicos e na maximização da receita e da arrecadação. Destaca ainda que o controle da economicidade inspira-se no princípio do custo-benefício.

Outrossim, reconhece que o tribunal de contas poderá controlar, sob o ponto de vista da economicidade, todos os incentivos fiscais e financeiros concedidos no âmbito da receita (isenções, créditos fiscais, deduções, abatimento, reduções de alíquotas, etc.) ou da despesa pública (restituições de tributos, subvenções, subsídios). E justifica a necessidade de tal controle em razão do abuso na concessão de incentivos, camuflados ou não, com reflexos negativos sobre as finanças públicas e a economia do País. Assinala: "Sabe-se da perversidade dos incentivos concedidos no Brasil nos últimos anos, alguns em franca contradição com os interesses ecológicos, econômicos e regionais" ${ }^{\prime 19}$.

Importante atentar, nos termos do pensamento do autor retro, que o controle da economicidade está inserido no controle da legitimidade. Este último envolve o bom uso dos recursos públicos, isto é, a verificação se o emprego dos recursos é socialmente desejado, tecnicamente factível e economicamente eficiente.

Assim sendo, as finanças públicas devem ser formalmente examinadas quanto à legalidade, quanto à gestão - justiça e custo-benefício - bem ainda se o cidadão realmente obtém a contrapartida do seu sacrifício econômico.

Maria Sylvia Zanella Di Pietro sustenta que o controle externo da economicidade, assim como da legitimidade, "envolve questão de mérito, para verificar se o

${ }^{18}$ FIGUEIREDO, Lúcia Valle. Curso de direito administrativo. p. 355.

19 TORRES, Ricardo Lobo. O Tribunal de Contas e o controle da legalidade, economicidade e legitimidade. Revista de Informação Legislativa. v. 31. n. 121. P. 265-271, jan./mar. de 1994. Disponível em: <http://www2.senado.gov.br/bdsf/bitstream/handle/id/176237/000488273.pdf?sequence $=1>$.Ac esso em: 06 jan. 2016. 
UCHOA, Adelaide Maria Rodrigues; RODRIGUES, Francisco Luciano Lima. Alienação de bens imóveis públicos em favor de particulares à luz dos princípios constitucionais da eficiência e economicidade. Revista Eletrônica Direito e Política, Programa de Pós-Graduação Stricto Sensu em Ciência Jurídica da UNIVALI, Itajaí, v.11, n.3, 30 quadrimestre de 2016. Disponível em: www.univali.br/direitoepolitica - ISSN 1980-7791.

órgão procedeu, na aplicação da despesa pública, de modo mais econômico, atendendo, por exemplo, uma adequada relação custo-benefício". Acrescenta que o artigo 71 da Constituição Federal de 1988 atribui aos tribunais de contas a função de julgamento, possibilitando a apreciação das contas dos administradores e demais responsáveis por dinheiros, bens e valores públicos e as contas daqueles que derem causa à perda, extravio ou outra irregularidade de que resulte prejuízo ao erário, contudo não julga a responsabilidade dos gestores, por ser competência do Poder Judiciário ${ }^{20}$.

Com efeito, deduz-se que o princípio constitucional da economicidade da gestão de recursos e bens públicos permite que as cortes de contas examinem as condutas dos gestores públicos no sentido de avaliar se os gastos ou investimentos públicos efetivados ensejam ganhos ou perdas sociais.

\section{ANÁlise dO CUSTO-BENEFÍCIO NA ALOCAÇÃO DOS INVESTIMENTOS PÚBLICOS RELATIVOS AOS BENS IMÓVEIS}

Não obstante existam várias formas de aquisição da propriedade imóvel pelos entes públicos, (compra, recebimento em doação, permuta, usucapião, acessão, execução, parcelamento para urbanização, confisco, desapropriação, reversão, dentre outras) serão aqui destacadas apenas dois modos aquisição da propriedade imobiliária: o loteamento e a desapropriação.

Tal escolha recaiu em tais modos aquisitivos por serem os meios de aquisição que quantitativamente mais resultam na formação do patrimônio público. Para melhor compreensão do aspecto que se quer abordar, faz-se imprescindível breve explanação sobre o processo de loteamento de áreas urbanas e a desapropriação de bens imóveis.

No caso de parcelamento do solo urbano, uma vez registrado o loteamento urbano aprovado pela Municipalidade, além da criação de lotes e quadras com destinação privada, são reservadas algumas áreas às quais é conferida

${ }^{20}$ DI PIETRO, Maria Sylvia Zanella. Direito administrativo. p. 808-809. 
UCHOA, Adelaide Maria Rodrigues; RODRIGUES, Francisco Luciano Lima. Alienação de bens imóveis públicos em favor de particulares à luz dos princípios constitucionais da eficiência e economicidade. Revista Eletrônica Direito e Política, Programa de Pós-Graduação Stricto Sensu em Ciência Jurídica da UNIVALI, Itajaí, v.11, n.3, 30 quadrimestre de 2016. Disponível em: www.univali.br/direitoepolitica - ISSN 1980-7791.

destinação pública, seja compondo o sistema viário, as áreas verdes ou as institucionais. Com o processo de urbanização, as áreas destacadas, passam, então, ao domínio do município, gratuitamente, a priori, por não depender de indenização ou de pagamento pelo bem. Sabe-se, no entanto, que futura e indiretamente, requesta-se uma contraprestação estatal, no sentido de prover a comunidade de infraestrutura básica para a habitabilidade do local e de manutenção dos equipamentos urbanos.

Já a desapropriação, instituto de direito público, é o procedimento pelo qual o Poder Público, em caso de necessidade ou de utilidade pública, ou ainda, de interesse social, retira da pessoa determinado bem, mediante prévia e justa indenização em dinheiro.

Em se tratando de reforma agrária ou urbana, a indenização será paga em títulos da dívida pública ou da dívida agrária e posteriormente à expropriação, como sanção pelo descumprimento da função social ou pela improdutividade da terra.

A desapropriação visa à retirada do bem do particular para fins de utilização em prol da coletividade, constituindo o motivo de utilidade (ou necessidade pública) ou o interesse social no fator determinante para a admissão de intervenção do Poder Público na propriedade privada.

Assim, ao promover a desapropriação, o Poder Público condiciona a legalidade de tal intervenção à efetiva utilização, conforme a destinação consentânea com o interesse público. Entretanto, por vezes esse bem expropriado acaba sendo transmitido a terceiro.

Carvalho Filho aduz que a regra é a permanência dos bens em propriedade da Administração, a qual deverá conservá-los adequadamente para evitar sua deterioração, posto integrarem o domínio público. Todavia, assenta que há situações em que a alienação dos bens públicos não somente pode ser conveniente para a Administração como ainda pode trazer-lhe outras vantagens ${ }^{21}$.

${ }^{21}$ CARVALHO FILHO, José dos Santos. Manual de direito administrativo. p. 1.296. 
UCHOA, Adelaide Maria Rodrigues; RODRIGUES, Francisco Luciano Lima. Alienação de bens imóveis públicos em favor de particulares à luz dos princípios constitucionais da eficiência e economicidade. Revista Eletrônica Direito e Política, Programa de Pós-Graduação Stricto Sensu em Ciência Jurídica da UNIVALI, Itajaí, v.11, n.3, 30 quadrimestre de 2016. Disponível em: www.univali.br/direitoepolitica - ISSN 1980-7791.

Ante o dispêndio de recursos públicos no processo de desapropriação, é questionável que o Poder Público adquira um bem de forma onerosa e, posteriormente, efetue doação em favor de empresa privada de fins lucrativos, a título de incentivo para se instalar em seu território. Mesmo porque a justa indenização a ser paga ao expropriado representa ônus a ser suportado exclusivamente pelo ente expropriante. Para se tornar uma medida eficiente, e, portanto, legítima, deveriam ser avaliados de modo exaustivos os custos e os reais benefícios ofertados à coletividade.

Maior parte das vezes, antes da tomada de decisões pelos gestores públicos, sequer é realizada avaliação detalhada dos impactos econômico-financeiros das aquisições onerosas de bens sobre o erário. Tal prática, obviamente, costuma resultar em decisões discricionárias, fundadas tão somente nas disposições legais não proibitivas do ato.

O suposto interesse público geralmente é o que justifica a medida eleita pelo gestor, o qual se ocupa, no máximo, em atender a previsão normativa para o ato. Com isso, descura-se da conduta eficiente vindicada na administração de coisa pública.

A averiguação criteriosa de todas as informações poderá proporcionar uma escolha racional por um determinado terreno a ser desapropriado. Então, a escolha será mais ou menos eficiente na obtenção de um resultado que afetará a sociedade. O direcionamento de determinado bem a certa atividade particular pode se revelar proveitoso ou não para o desenvolvimento do munícipio. E este é o ponto: buscar alocar os investimentos públicos de modo que reflita a melhor solução para a coletividade, legítima titular do bem público.

No jogo de interesses, deverá invariavelmente ser ponderado se o desenvolvimento sustentável das cidades está sendo comprometido por decisões ineficientes. Deverá o administrador sopesar os ganhos e as perdas que uma escolha poderá representar para os administrados, já que em favor deles é que se gere a coisa pública. Igualmente não se olvide que o dever de prestação de contas decorre da obrigação de bem administrar, e é fundamental a 
UCHOA, Adelaide Maria Rodrigues; RODRIGUES, Francisco Luciano Lima. Alienação de bens imóveis públicos em favor de particulares à luz dos princípios constitucionais da eficiência e economicidade. Revista Eletrônica Direito e Política, Programa de Pós-Graduação Stricto Sensu em Ciência Jurídica da UNIVALI, Itajaí, v.11, n.3, 30 quadrimestre de 2016. Disponível em: www.univali.br/direitoepolitica - ISSN 1980-7791.

demonstração de que a conduta do gestor não tenha carreado prejuízos, mesmo que indiretos.

O raciocínio da teoria econômica principia pela escassez de recursos antes às demandas humanas ilimitadas, o que invariavelmente gera um problema de alocação desses recursos.

Diante disso, é que as pessoas, aí incluídos os gestores públicos, deverão direcionar as próprias escolhas, avaliando se o ganho decorrente daquela conduta supera o custo que terá. Ou seja, a análise do custo-benefício, deverá guiar a escolha racional e isto é um processo comum às relações de modo geral, já que a tendência das pessoas, públicas ou privadas, é maximizar sua satisfação, adotando-se padrões objetivos para as respectivas escolhas.

Segundo Diogo Naves Mendonça os parâmetros fornecidos pela microeconomia propiciam decisões racionais no sentido de maximizar a alocação de recursos escassos entre fins alternativos, o que tende a levar ao equilíbrio ${ }^{22}$. E retorna-se novamente ao problema da eficiência, sob o prisma econômico, que, traduzido na maximização da riqueza, envolve a relação entre custos e benefícios e contribui para a discussão de justiça. Não há, portanto, como abstrair a importância da análise econômica nas decisões jurídicas.

Sem afastar o intérprete do direito da análise da legalidade da decisão, judicial ou extrajudicial, a qual exige adequação às normas jurídicas - regras e princípios, deve-se proceder a avaliação da eficiência complementarmente à análise jurídica. Segundo Mendonça, a solução justa, partindo-se da análise dos possíveis resultados, poderá ser eficiente ou ineficiente, não havendo como predizer acerca disso, todavia a avaliação de consequências tem certa utilidade, na minimização dos riscos ${ }^{23}$.

\footnotetext{
22 MENDONÇA, Diogo Naves. Análise econômica da responsabilidade civil. $O$ dano e a sua quantificação. São Paulo: Atlas, 2012, p. 20.

23 MENDONÇA, Diogo Naves. Análise econômica da responsabilidade civil. $O$ dano e a sua quantificação. p. 31.
} 
UCHOA, Adelaide Maria Rodrigues; RODRIGUES, Francisco Luciano Lima. Alienação de bens imóveis públicos em favor de particulares à luz dos princípios constitucionais da eficiência e economicidade. Revista Eletrônica Direito e Política, Programa de Pós-Graduação Stricto Sensu em Ciência Jurídica da UNIVALI, Itajaí, v.11, n.3, 30 quadrimestre de 2016. Disponível em: www.univali.br/direitoepolitica - ISSN 1980-7791.

Questão emblemática é a alocação de recursos públicos, por natureza coletivos e administrados por gestores não proprietários. Fundamental então a análise de custos e benefícios quando se trata de decisões que os envolvam, que reclamem a melhor utilização possível.

Devem ser analisadas as formas pelas quais se torna possível estimar, em termos econômicos, as externalidades presentes nos projetos voltados a obras públicas.

Para Leonardo Figueira nada obsta a que a análise de custo-benefício, instrumento bastante consagrado de avaliação de projetos (inclusive privados), seja aplicada como ferramenta auxiliar ao processo decisório relativo à eficiente alocação dos investimentos públicos. E reproduz os estágios desenvolvidos por Cole pelos quais deverá perpassar a análise de custo-benefício:

Cole (2009: 3) sintetiza a Análise de Custo-Benefício em seis estágios, quais sejam: "(1) identificar a ação coletiva ou problema gerador de custo social e determinar metas; (2) identificar políticas alternativas, incluindo a inação; (3) determinar os impactos previsíveis (incluindo impactos externos ao mercado) de cada alternativa, durante sua respectiva duração ou vida útil; (4) atribuir valores a esses impactos - (a) impactos favoráveis são denominados benefícios, (b) impactos desfavoráveis são denominados custos; (5) descontar os custos e benefícios futuros a valores presentes e calcular o benefício (ou custo) presente líquido de cada alternativa; (6) finalmente, comparar o benefício (ou custo) presente líquido de cada alternativa e eleger a alternativa com os maiores benefícios ou menores custos $^{24}$.

Outro ponto a ser realçado é a afetação e, consequente exploração econômica de bens públicos já pertencentes ao domínio estatal. A ausência de fiscalização e a falta de um rígido controle cadastral de bens imóveis de propriedade do ente público concorrem sobremaneira para a malversação desses bens, propiciando, dentre outras práticas, a invasão de terras (que requer propositura de ações

24 FIGUEIRA, Leonardo M. Proposta de metodologia para mensuração dos benefícios econômicos da implantação de infraestruturas de transporte: modais aéreo e terrestre. Disponível em: <http://webcache.googleusercontent.com/search?q=cache:dVuH8aXobK0J:portal2.tcu.gov.br/po rtal/pls/portal/docs/2510075.PDF+\&cd=1\&hl=pt-PT\&ct=clnk\&gl=br>. Acesso em: 06 jan. 2016. 
UCHOA, Adelaide Maria Rodrigues; RODRIGUES, Francisco Luciano Lima. Alienação de bens imóveis públicos em favor de particulares à luz dos princípios constitucionais da eficiência e economicidade. Revista Eletrônica Direito e Política, Programa de Pós-Graduação Stricto Sensu em Ciência Jurídica da UNIVALI, Itajaí, v.11, n.3, 30 quadrimestre de 2016. Disponível em: www.univali.br/direitoepolitica - ISSN 1980-7791.

possessórias) e a devolução de verbas federais destinadas a projetos sociais pela ausência de documentação referente a propriedade. Isto é, a falha na gestão do patrimônio imobiliário público resulta na alocação ineficiente de recursos já escassos, a exemplo da propriedade.

A decisão do gestor público deve orientar-se não só pela legalidade como também pela eficiência. Nessa senda, a atuação daquele que se afasta da eficiência e da economicidade e atua discricionariamente, alienando gratuitamente bens públicos, sem atentar para os critérios de equilíbrio, justiça, vem sendo discutida pelos Tribunais de Contas, órgãos competentes para examinar as contas dos gestores públicos.

As questões principais acerca de tais condutas e a responsabilidade pela malversação dos bens que administra, resumem-se ao processo de escolha que exige daqueles gestores uma decisão motivada sobre a efetuação de transmissões onerosas ou gratuitas, sobre quem poderá receber os bens públicos, tudo isso somado ao deficiente disciplinamento legal da matéria.

Acerca da regularização fundiária de favelas no Rio de Janeiro, Rose Compans frisa que a Lei Orgânica do Estado do Rio de Janeiro previu expressamente que a concessão de direito real de uso deve ser priorizada ante o instituto da doação nos casos de assentamentos populacionais em imóveis públicos ${ }^{25}$.

A Lei Orgânica do Município de Teresina-Piauí, atenta a essa orientação conferiu preferência à concessão de direito real de uso frente à doação ou mesmo alienação de bens ${ }^{26}$. Já a Lei Orgânica do Município de Fortaleza -Ceará sequer menciona o uso da concessão de direito real em substituição da doação.

25 COMPANS, Rose. A regularização fundiária de favelas no Estado do Rio de Janeiro. Revista Rio de Janeiro, n. 9, p. 41-53, jan./abr. 2003, Disponível em <http://www.forumrio.uerj.br/documentos/revista_9/009_041.pdf >. Acesso em: 06 jan. 2016.

26 TERESINA [Município]. Lei Orgânica do Município de Teresina. Disponível em: <http://pgm.teresina.pi.gov.br/admin/upload/documentos/77f11ae101.pdf>. Acesso em: 06 jan. 2016. Conforme: Art. 115. O Município, preferentemente à venda ou à doação de bens imóveis, concederá direito real de uso, mediante concorrência. Parágrafo Único - A concorrência poderá ser dispensada, quando o uso destinar-se à concessionária de serviço público, às entidades assistenciais ou verificar-se relevante interesse público na concessão, devidamente justificado. 
UCHOA, Adelaide Maria Rodrigues; RODRIGUES, Francisco Luciano Lima. Alienação de bens imóveis públicos em favor de particulares à luz dos princípios constitucionais da eficiência e economicidade. Revista Eletrônica Direito e Política, Programa de Pós-Graduação Stricto Sensu em Ciência Jurídica da UNIVALI, Itajaí, v.11, n.3, 30 quadrimestre de 2016. Disponível em: www.univali.br/direitoepolitica - ISSN 1980-7791.

Apresenta tão somente os critérios para alienação de bens imóveis públicos, reforçando a dispensa de licitação nos casos de urbanização de favelas e restringe a possibilidade de uso particular ou transmissão de áreas verdes e demais logradouros ${ }^{27}$.

Diante disso, vale destacar o teor de decisões e recomendações dos tribunais de contas, que em certas circunstâncias, admitem doação de bens públicos, além das hipóteses elencadas no artigo 17 da lei 8.666/93 e noutras, diante da falta de normatização específica, recomendam instrumentos de cessão dos bens: concessão de direito real de uso (CDRU) ou concessão de uso especial para fins de moradia (CUEM).

Algumas cortes de contas, a exemplo do Tribunal de Contas do Estado de Minas Gerais e do Estado do Mato Grosso, vem decidindo sobre a possibilidade de doação de bens públicos, sempre realçando os requisitos gerais e inovando com sugestões para o alcance da eficiência.

O Plenário do Tribunal de Contas do Estado de Minas Gerais, na Consulta no 835.894 decidiu sobre a possibilidade de doação de bens públicos a pessoas comprovadamente carentes, orientando pela preferência dos institutos da concessão de direito real de uso e da concessão especial para fins de moradia à doação, os quais admitem maior controle quanto à preservação da finalidade social do uso pelo particular e não se traduzem em mera disponibilidade do patrimônio público ${ }^{28}$.

Mais especificamente, na Consulta no 498.790, relatada pelo Conselheiro Simão Pedro, o mesmo Plenário do Tribunal de Contas do Estado de Minas Gerais, já

27 FORTALEZA [Município]. Lei Orgânica do Município de Fortaleza. Disponível em: <http://www.pgj.ce.gov.br/AdmSuperior/assessorias/acc/lom/fortaleza.pdf>. Acesso em: 06 jan. 2016.

28 EMENTA: Consulta - Câmara Municipal - Doação de bens imóveis públicos a pessoas comprovadamente carentes - Possibilidade - Autorização legislativa - Avaliação prévia Irrefutável demonstração de interesse social - Licitação dispensada na hipótese do art. 17, I, f, da Lei n. 8.666/93 - Caráter excepcional - Preferência pela adoção dos institutos da concessão de direito real de uso e da concessão especial para fins de moradia - Vinculação a políticas públicas consistentes, de interesse social - Observância aos princípios administrativos, notadamente os da impessoalidade e da moralidade. (CONSULTA N. 835.894) Conforme: MINAS GERAIS [Estado]. TRIBUNAL DE CONTAS DO ESTADO DE MINAS GERAIS. Decisões. Consulta no 835894. Disponível em: <http://tcjuris.tce.mg.gov.br>.Acesso em: 06 jan. 2016. 
UCHOA, Adelaide Maria Rodrigues; RODRIGUES, Francisco Luciano Lima. Alienação de bens imóveis públicos em favor de particulares à luz dos princípios constitucionais da eficiência e economicidade. Revista Eletrônica Direito e Política, Programa de Pós-Graduação Stricto Sensu em Ciência Jurídica da UNIVALI, Itajaí, v.11, n.3, 30 quadrimestre de 2016. Disponível em: www.univali.br/direitoepolitica - ISSN 1980-7791.

havia reconhecido os requisitos para a transmissão de bens públicos. Reafirmou as exigências do art. 17 da Lei 8.666/93: necessidade de existência de interesse público justificado, autorização legislativa e avaliação prévia, condicionada a transmissão do município à efetiva implementação de políticas públicas de interesse local $^{29}$.

Admitindo a doação de imóveis apenas em caráter excepcional e vinculada a projetos habitacionais, o Tribunal de Contas do Estado de Minas Gerais, passou a repensar a transmissão gratuita de bens públicos em favor de particulares, analisando-se também a questão sob a ótica da opção mais vantajosa ao ente público $^{30}$.

O Tribunal de Contas dos Municípios do Mato Grosso se posicionou admitindo a doação de imóveis públicos, contudo apontou mais uma condicionante: será considerada legítima se for efetuada com encargo e com restrição à doação em ano eleitoral ${ }^{31}$.

${ }^{29}$ MINAS GERAIS [Estado]. TRIBUNAL DE CONTAS DO ESTADO DE MINAS GERAIS. Decisões. Consulta no 498790. Disponível em: <http://tcjuris.tce.mg.gov.br>. Acesso em: 06 jan. 2016.

30 minAS Gerais [Estado]. Revista TCE-MG. Patrimônio Público. Disponível em: < http://revista.tce.mg.gov.br/Content/Upload/Materia/1385.pdf>. Acesso em: 06 jan. 2016. Bens públicos. Adoção da concessão de direito real de uso e da concessão especial para fins de moradia]. Possibilidade de doação, em caráter excepcional, de imóveis a particulares 1) No que diz respeito aos bens imóveis de propriedade do município ocupados por pessoas carentes que estabeleceram lá sua residência, sob o ponto de vista do interesse público, é mais vantajoso para o município a adoção do instituto da concessão de direito real de uso e da concessão especial para fins de moradia, que permitem maior controle quanto à preservação da finalidade social do uso pelo particular e não configuram mera disponibilidade do patrimônio público $(\ldots) ; 2$ ) Possibilidade de o município realizar doação, em caráter excepcional, dos imóveis de sua propriedade, ocupados por pessoas carentes, desde que vinculada a políticas públicas consistentes, sob autorização legislativa, avaliação prévia, indiscutível demonstração de interesse social e licitação (dispensada nos casos do art. 17, I, f, da Lei Federal n. 8.666/93), observados os princípios administrativos, notadamente os da impessoalidade e da moralidade (Consulta $\mathrm{n}$. 862440. Rel. Cons. Mauri Torres. Publicada no D.O.C. em 24/11/2011).

${ }^{31}$ MATO GROSSO [Estado]. TRIBUNAL DE CONTAS DO ESTADO DO MATO GROSSO. Decisão. Processo no 18.065-3/2008. Disponível em: <http://jurisdicionado.tce.mt.gov.br/protocolo/decisao/num/180653/ano/2008/num_decisao/5/a no_decisao/2009>. Acesso em 06 jan. 2016. "Tribunal de Contas dos Municípios do Mato Grosso "Processo no 18.065-3/2008 Interessada: Prefeitura Municipal de Diamantino 1 - A doação de bem público imóvel exige: a) desafetação, se for o caso; b) autorização em lei específica; c) tratar de interesse público devidamente justificado; d) prévia avaliação do imóvel; e) dispensada a licitação, nas hipóteses previstas em lei, inclusive para as alienações gratuitas no âmbito de programas habitacionais ou de regularização fundiária de interesse social (art. 17, inciso I, alíneas "b", "f" e "h", da Lei no 8.666/93); 2 - Os Estados, Municípios e o Distrito Federal poderão doar bens públicos a pessoa jurídica de direito privado, em razão dos efeitos da liminar concedida pelo STF na ADI no 927. Todavia, a doação deverá sempre atender ao 
UCHOA, Adelaide Maria Rodrigues; RODRIGUES, Francisco Luciano Lima. Alienação de bens imóveis públicos em favor de particulares à luz dos princípios constitucionais da eficiência e economicidade. Revista Eletrônica Direito e Política, Programa de Pós-Graduação Stricto Sensu em Ciência Jurídica da UNIVALI, Itajaí, v.11, n.3, 30 quadrimestre de 2016. Disponível em: www.univali.br/direitoepolitica - ISSN 1980-7791.

O Poder Judiciário, por vezes, decidindo sobre a alienação de bem público imóvel, e diante da ausência de previsão em leis orgânicas municipais, chega a admitir, além da alienação gratuita, a possibilidade de transmissão onerosa ao particular por venda, desde que cumpridos os requisitos: motivação pelo interesse público, autorização legislativa para o ato, avaliação prévia e processo licitatório.

Em 2009 o Tribunal de Justiça do Estado de Santa Catarina manifestou-se sobre a matéria admitindo a doação de bem público para fim de instalação de empresa privada e considerando dispensável o processo licitatório em razão de ter sido comprovado o interesse público na transmissão gratuita ${ }^{32}$.

O mesmo TJSC, em 2011, apreciou pleito que versava sobre a venda de imóvel público sem licitação e decidiu por considerar que não foram atendidos os requisitos da Lei no 8.666/93. O respectivo aresto, desde então, vem sendo constantemente reproduzido em decisões de vários outras cortes, a exemplo do Tribunal de Alagoas e do Tribunal Regional Federal da $3^{a}$ Região ${ }^{33}$.

interesse público, sendo vedada qualquer conduta que implique em violação aos princípios da isonomia ou igualdade, da moralidade e da impessoalidade (arts. 50, caput, e 37, caput, ambos da Constituição Federal Brasileira); e 3 - É vedada a doação de quaisquer bens públicos, valores ou benefícios no ano eleitoral (10 de janeiro a 31 de dezembro), salvo nos casos de calamidade pública, estado de emergência ou inseridos em programas sociais autorizados em lei e já em execução orçamentária no exercício anterior (art. 73, parágrafo 10, da Lei n0 9.504/1997)"

32 SANTA CATARINA [Estado]. TRIBUNAL DE JUSTIÇA DE SANTA CATARINA. AC 385157 SC 2006.038515-7, Rel. Ricardo Roesler, 2a Câmara de direito Público, J. 20/02/2009. Disponível em:<http://tj-sc.jusbrasil.com.br/jurisprudencia/6522345/apelacao-civel-ac-385157-sc-

2006038515-7/inteiro-teor-12627221>. Acesso em: 06 jan. 2016. EMENTA: Apelação cível. Ação cominatória. Doação de imóvel público à particular. Outorga de escritura pública. Encargos cumpridos. Sentença de improcedência ao argumento de não ter sido observado processo licitatório. Doação fundada em interesse público justificado. Possibilidade de dispensa da licitação. Outorga de escritura pública devida. Recurso provido. A doação de bem público, através de lei específica, à empresa privada para atrair sua instalação, refletindo no incremento da economia e na melhoria das condições sociais, atende ao interesse público. (TJSC, AC 385157 SC 2006.038515-7, Rel. Ricardo Roesler, 2a Câmara de direito Público, J. 20/02/2009)

33 EMENTA: Processual Civil. Julgamento antecipado da lide. Prova exclusivamente documental. Cerceamento de defesa. Inocorrência. O Magistrado pode e deve exercer juízo crítico e aceitar como suficientes as provas documentais apresentadas, dispensando as outras, quando a tendência é que a lide seja julgada antecipadamente, conforme o previsto pelo Código de Processo Civil, art. 330, inc. I. Administrativo - Alienação de bem público imóvel - Lei $\mathrm{n}$. 8.666/93, art. 17, inc. I - Necessidade de demonstração de interesse público, autorização legislativa, avaliação prévia e procedimento licitatório - Ausência de provas do cumprimento das formalidades legais - Nulidade do contrato administrativo. A alienação de bem público imóvel, a rigor, está condicionada ao preenchimento das seguintes formalidades administrativas: (a) demonstração de interesse público, (b) autorização legislativa, (c) avaliação prévia e (d) 
UCHOA, Adelaide Maria Rodrigues; RODRIGUES, Francisco Luciano Lima. Alienação de bens imóveis públicos em favor de particulares à luz dos princípios constitucionais da eficiência e economicidade. Revista Eletrônica Direito e Política, Programa de Pós-Graduação Stricto Sensu em Ciência Jurídica da UNIVALI, Itajaí, v.11, n.3, 30 quadrimestre de 2016. Disponível em: www.univali.br/direitoepolitica - ISSN 1980-7791.

Depreende-se, pois, que as decisões das cortes de contas decorrem da análise das condutas do administrador, na utilização adequada dos recursos públicos e embora não revistam poder de atribuir responsabilidade, devem observar as normatizações já declinadas e o princípio da reserva do possível.

Com o princípio da reserva do possível, é certo que a implementação de um direito a prestação exige a alocação de recursos, conforme o caso concreto. Nesse aspecto, haverá destinação de recursos públicos - financeiros ou não, para o atendimento de um direito individual desde que não comprometa o direito da coletividade. Por outro lado, o Poder Judiciário, ao julgar demandas que importem em indevida alocação de recursos, deverá levar em conta que a decisão proferida poderá incentivar ou desestimular práticas ineficientes e, sobretudo, nocivas à coletividade.

\section{CONSIDERAÇÕES FINAIS}

A doação de bens públicos em favor de particulares não é matéria pacificada doutrinariamente nem jurisprudencialmente em face das peculiaridades do regime jurídico a que se submetem os bens públicos bem como das omissões da legislação infraconstitucional, especialmente no tocante ao artigo 17 da Lei $8.666 / 93$.

De modo geral, a doação de bens públicos, para ser lícita, necessita de desafetação, prévia autorização legislativa, avaliação, procedimento licitatório e atendimento ao interesse público. Todavia a questão da doação dos bens

procedimento licitatório na modalidade de concorrência. Nessa perspectiva, é nula a venda de imóvel promovida pela Administração se desprovida de autorização legislativa e licitação prévia. (TJ/SC AC 585 SC 2011.000058-5, Rel. Luiz César Medeiros, 3a Câmara de Direito Público, julgamento 16/06/2011) Conforme: ALAGOAS [Estado]. Andamento do Processo no 000687589.1999.8.02.0001 - Apelação - 18/12/2015 do TJAL. JUS BRASIL. Disponível em: <http://www.jusbrasil.com.br/diarios/documentos/270451966/andamento-do-processo-n0006875-8919998020001-apelacao-18-12-2015-do-tjal>. Acesso em: 06 jan. 2016. Posicionamento acompanhado também pelo TRF da $3^{\mathrm{a}}$ Região em ação de Reintegração/manutenção de posse. Proc. No 0003708-68.2011.403.6106. BUSCA OFICIAL DO DIÁRIO OFICIAL DO BRASIL. <http://www.buscaoficial.com/c/diario/cG4Aam7Fg>. Acesso em: 06 jan. 2016. 
UCHOA, Adelaide Maria Rodrigues; RODRIGUES, Francisco Luciano Lima. Alienação de bens imóveis públicos em favor de particulares à luz dos princípios constitucionais da eficiência e economicidade. Revista Eletrônica Direito e Política, Programa de Pós-Graduação Stricto Sensu em Ciência Jurídica da UNIVALI, Itajaí, v.11, n.3, 30 quadrimestre de 2016. Disponível em: www.univali.br/direitoepolitica - ISSN 1980-7791.

públicos deve ser analisada sob duas perspectivas: da regularização fundiária e do desenvolvimento sustentável das cidades.

Objetivando conservar a integridade do patrimônio público, e alinhado com as diretrizes da Política Urbana, o legislador infraconstitucional priorizou o direito de moradia, reforçando a importância de dois institutos: a concessão de direito real de uso (CDRU) e a concessão de uso especial para fins de moradia (CUEM). A fim de conferir mais segurança aos cessionários, estes institutos foram erigidos também ao número fechado de direitos reais consignados no artigo 1225 do Código Civil de 2002.

Também é sabido que Estados e Municípios tem oferecido às empresas privadas de fins lucrativos, a título de incentivo para se instalarem em seus territórios, muitas vantagens que vão desde a doação de terrenos e a isenção temporária de tributos até a implantação de infraestrutura para que tais empresas possam iniciar as atividades em troca de promessas de criação de vagas de trabalho para acolher os munícipes e de aumento na arrecadação tributária, ao final do período de isenção.

Todavia o Município, dentro de sua autonomia administrativa, pode normatizar regras sobre alienações, desde que respeitadas as normas gerais prescritas na Lei no 8.666/93 e os dispositivos da Constituição Federal, que entre outros, consagra os princípios da isonomia e da impessoalidade (arts. 50, caput e 37, caput, ambos da CF/88), pressupostos do procedimento concorrencial.

No que tange à doação de bens públicos, a concessão de incentivos econômicos em favor empresas privadas de fins lucrativos, deve ser cautelosamente examinada.

O gestor público, na qualidade administrador de coisa alheia com dever de prestação de contas, não poderá se afastar dos princípios que regem a atividade pública: legalidade, impessoalidade, moralidade, publicidade e eficiência. Compete ao gestor da coisa pública conferir aos bens públicos uma exploração econômica compatível com a destinação do bem e decidir pela melhor forma de aproveitamento dos bens. 
UCHOA, Adelaide Maria Rodrigues; RODRIGUES, Francisco Luciano Lima. Alienação de bens imóveis públicos em favor de particulares à luz dos princípios constitucionais da eficiência e economicidade. Revista Eletrônica Direito e Política, Programa de Pós-Graduação Stricto Sensu em Ciência Jurídica da UNIVALI, Itajaí, v.11, n.3, 30 quadrimestre de 2016. Disponível em: www.univali.br/direitoepolitica - ISSN 1980-7791.

Assim sendo, a decisão pela doação ou pela utilização de outros modos de transmissão de bens públicos requer análise dos custos e dos benefícios que serão auferidos a coletividade e otimização da alocação dos investimentos públicos, costumeiramente objetos de decisões políticas, e, como isso, não racionais.

Deverá o administrador público atuar de modo eficiente, sem se afastar da lei. $\mathrm{Na}$ ponderação entre legalidade e eficiência ainda deverá ser considerado outro princípio: o da economicidade, cuja utilização poderá ensejar redução dos custos e maximização da satisfação da coletividade. Nesse aspecto a decisão do gestor público deve pautar-se não só pela legalidade como também pela eficiência e pela economicidade.

Além de juridicamente motivada, a análise da eficiência e economicidade da decisão adotada deve recair em inúmeros pontos, exemplificadamente: se deve ou não efetuar transmissões de bens; se tais transmissões devem ser onerosas ou gratuitas; dentre as transmissões gratuitas, qual opção oportunizará mais benefícios ou implicará menor custo; qual decisão ensejará maior grau da satisfação a sociedade; se a concessão ou não de incentivos fiscais econômicos representa possibilidade real de desenvolvimento.

Questões envolvendo a adequada destinação de bens públicos têm chegado às cortes de contas, por meio de consultas, e ao Poder Judiciário, nos casos de malversação de bens e violação de direitos originados das alienações indevidas ou ilegais. Nesta matéria, os tribunais de contas tem admitido a doação de bens imóveis em certas circunstâncias que envolvem regularização fundiária, não obstante venham sugerindo a substituição do ato de doação pela concessão do direito real de uso sobre o bem público, o que nem sempre é acatado pelo gestor público, posto se tratar de recomendação.

Por outro lado, o Poder Judiciário, ao julgar demandas que importem em indevida alocação de recursos, deverá levar em conta que tal decisão poderá incentivar ou desestimular práticas ineficientes e, sobretudo, perniciosas aos interesses da sociedade, e imputar ao gestor que opta por medidas ineficientes e 
UCHOA, Adelaide Maria Rodrigues; RODRIGUES, Francisco Luciano Lima. Alienação de bens imóveis públicos em favor de particulares à luz dos princípios constitucionais da eficiência e economicidade. Revista Eletrônica Direito e Política, Programa de Pós-Graduação Stricto Sensu em Ciência Jurídica da UNIVALI, Itajaí, v.11, n.3, 30 quadrimestre de 2016. Disponível em: www.univali.br/direitoepolitica - ISSN 1980-7791.

temerárias, as sanções apropriadas, especialmente a responsabilização pelos danos causados a sociedade, decorrentes de decisões antieconômicas.

\section{REFERÊNCIAS DAS FONTES CITADAS}

ALAGOAS [Estado]. Andamento do Processo no 000687589.1999.8.02.0001 - Apelação - 18/12/2015 do TJAL. JUS BRASIL. Disponível em: <http://www.jusbrasil.com.br/diarios/documentos/270451966/andamento-doprocesso-n-0006875-8919998020001-apelacao-18-12-2015-do-tjal>. Acesso em: 06 jan. 2016.

BERCOVICI, Gilberto. Constituição econômica e desenvolvimento. Uma leitura a partir da Constituição de 1988. São Paulo: Malheiros, 2005.

BRASIL. Tribunal Regional Federal - $3^{a}$ Região. Reintegração/manutenção de posse.. Proc. No 0003708-68.2011.403.6106. BUSCA OFICIAL. Disponível em: <http://www.buscaoficial.com/c/diario/cG4Aam7Fg>. Acesso em: 06 jan. 2016.

BUGARIN, Paulo Soares. Reflexões sobre o princípio constitucional da economicidade e o papel do TCU. IN: Revista do Tribunal de Contas da União - R.TCU, Brasília, v. 29 , n. 78, out/dez 1998. Disponível em: $<$ http://docplayer.com.br/8413952-Revista-do-tribunal-de-contas-dauniao.html>. Acesso em: 05 dez. 2015.

CARVALHO FILHO, José dos Santos. Manual de direito administrativo. 23. ed. rev., ampl. e atual., 2a tiragem, Rio de Janeiro: Lúmen Júris, 2010.

COLE, D. H. Regulatory Cost-Benefit Analysis and Collective Action. Working Paper 2009/1. Institute for Policy Integrity. New York University School of Law, 2009, apud FIGUEIRA, Leonardo M. Proposta de metodologia para mensuração dos benefícios econômicos da implantação de infraestruturas de transporte: modais aéreo e terrestre. Disponível em: http://portal2.tcu.gov.br/portal/pls/portal/docs/2510075.PDF. Acesso em: 07 jun. 2016.

COMPANS, Rose. A regularização fundiária de favelas no Estado do Rio de Janeiro. Revista Rio de Janeiro, n. 9, p. 41-53, jan./abr. 2003, Disponível em <http://www.forumrio.uerj.br/documentos/revista_9/009_041.pdf >. Acesso em: 06 jan. 2016.

DI PIETRO, Maria Sylvia Zanella. Direito administrativo. 25. ed. São Paulo: Atlas, 2012.

FIGUEIRA, Leonardo M. Proposta de metodologia para mensuração dos benefícios econômicos da implantação de infraestruturas de transporte: 
UCHOA, Adelaide Maria Rodrigues; RODRIGUES, Francisco Luciano Lima. Alienação de bens imóveis públicos em favor de particulares à luz dos princípios constitucionais da eficiência e economicidade. Revista Eletrônica Direito e Política, Programa de Pós-Graduação Stricto Sensu em Ciência Jurídica da UNIVALI, Itajaí, v.11, n.3, 30 quadrimestre de 2016. Disponível em: www.univali.br/direitoepolitica - ISSN 1980-7791.

modais aéreo e terrestre. Disponível em: <http://webcache.googleusercontent.com/search?q=cache:dVuH8aXobK0J:porta 12.tcu.gov.br/portal/pls/portal/docs/2510075.PDF+\&cd=1\&hl=pt-

PT\&ct $=$ clnk\&gl=br> . Acesso em: 06 jan. 2016.

FIGUEIREDO, Lúcia Valle. Curso de direito administrativo. 7.ed. São Paulo: Malheiros, 2005.

MATO GROSSO [Estado]. TRIBUNAL DE CONTAS DO ESTADO DO MATO GROSSO. Decisão. Processo no 18.065-3/2008. Disponível em: <http://jurisdicionado.tce.mt.gov.br/protocolo/decisao/num/180653/ano/2008/n um_decisao/5/ano_decisao/2009>. Acesso em: 06 jan. 2016.

MEIRELLES, Hely Lopes. Direito Administrativo Brasileiro. 21. ed. São Paulo: Malheiros, 1996

Direito de construir. 9. ed. atual. São Paulo: Malheiros, 2005.

MINAS GERAIS [Estado]. Revista TCE-MG. Patrimônio Público. Disponível em: $<$ http://revista.tce.mg.gov.br/Content/Upload/Materia/1385.pdf>. Acesso em: 06 jan. 2016.

. TRIBUNAL DE CONTAS DO ESTADO DE MINAS GERAIS. Decisões. Consulta no 835894. Disponível em: <http://tcjuris.tce.mg.gov.br>.Acesso em: 06 jan. 2016.

. TRIBUNAL DE CONTAS DO ESTADO DE MINAS GERAIS. Decisões. Consulta no 498790. Disponível em: <http://tcjuris.tce.mg.gov.br>. Acesso em: 06 jan. 2016.

MENDONÇA, Diogo Naves. Análise econômica da responsabilidade civil. $O$ dano e a sua quantificação. São Paulo: Atlas, 2012.

SANTA CATARINA [Estado]. TRIBUNAL DE JUSTIÇA DE SANTA CATARINA. AC 385157 SC 2006.038515-7. JUS BRASIL. Disponível em: http://tjsc.jusbrasil.com.br/jurisprudencia/6522345/apelacao-civel-ac-385157-sc2006038515-7/inteiro-teor-12627221. Acesso em: 06 jan. 2016.

SOUTO, Marcos Juruena Villela. Direito administrativo em debate. $2^{a}$ série. Rio de Janeiro: Lúmen Júris, 2007.

TEPEDINO, Gustavo; Fachin, Luiz Edson (Org.). Diálogos sobre direito civil. Rio de Janeiro: Renovar, 2012. v. III, p. 142.

TORRES, Ricardo Lobo. O Tribunal de Contas e o controle da legalidade, economicidade e legitimidade. Revista de Informação Legislativa. v. 31. n. 121. P. 265-271, jan./mar. de 1994. Disponível em: <http://www2.senado.gov.br/bdsf/bitstream/handle/id/176237/000488273.pdf? sequence $=1>$. Acesso em: 06 jan. 2016. 
UCHOA, Adelaide Maria Rodrigues; RODRIGUES, Francisco Luciano Lima. Alienação de bens imóveis públicos em favor de particulares à luz dos princípios constitucionais da eficiência e economicidade. Revista Eletrônica Direito e Política, Programa de Pós-Graduação Stricto Sensu em Ciência Jurídica da UNIVALI, Itajaí, v.11, n.3, 30 quadrimestre de 2016. Disponível em: www.univali.br/direitoepolitica - ISSN 1980-7791.

VENTURI, Thaís G. Pascoaloto. A análise consequencialista no processo de tomadas das decisões judiciais a partir da obra de Ricardo L. Lorenzetti. In: TEPEDINO, Gustavo; Fachin, Luiz Edson (Org.). Diálogos sobre direito civil. Rio de Janeiro: Renovar, 2012. v. III.

\section{Leis pesquisadas:}

BRASIL. Decreto-lei no 271, de 28 de fevereiro de 1967. Dispõe sôbre loteamento urbano, responsabilidade do loteador concessão de uso e espaço aéreo e dá outras providências. Disponível em: <http://www.planalto.gov.br/ccivil_03/decreto-lei/del0271.htm>. Acesso em: 06 jan. 2016.

Constituição Federal de 1988. Disponível em:

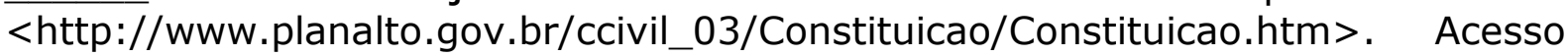
em: 06 jan. 2016.

Lei no 8.666, de 21 de junho de 1993. Regulamenta o art. 37, inciso XXI, da Constituição Federal, institui normas para licitações e contratos da Administração Pública e dá outras providências. Disponível em: <http://www.planalto.gov.br/ccivil_03/leis/L8666compilado.htm>. Acesso em: 06 jan. 2016.

- Lei Complementar no 101, de 04 de maio de 2000. Estabelece normas de finanças públicas voltadas para a responsabilidade na gestão fiscal e dá outras providências. Disponível em: <http://www.planalto.gov.br/ccivil_03/LEIS/LCP/Lcp101.htm>. Acesso em: 06 jan. 2016.

Lei no 10.257, de 10 de julho de 2001. Regulamenta os artigos 182 e 183 da Constituição Federal, estabelece diretrizes gerais da política urbana e dá outras providências. Disponível em: <http://www.planalto.gov.br/ccivil_03/Leis/LEIS_2001/_Quadro-2001.htm>. Acesso em: 06 jan. 2016.

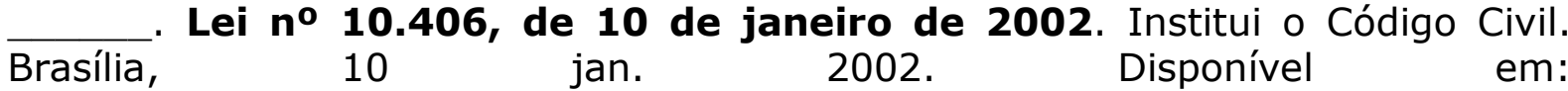
<http://www.planalto.gov.br/ccivil_03/Leis/2002/L10406.htm>. Acesso em: 06 jan. 2016.

Lei no 11.481, de 31 de maio de 2007. Dá nova redação a dispositivos das Leis nos 9.636, de 15 de maio de 1998, 8.666, de 21 de junho de 1993, 11.124, de 16 de junho de 2005, 10.406, de 10 de janeiro de 2002 Código Civil, 9.514, de 20 de novembro de 1997, e 6.015, de 31 de dezembro de 1973, e dos Decretos-Leis nos 9.760, de 5 de setembro de 1946, 271, de 28 de fevereiro de 1967, 1.876, de 15 de julho de 1981, e 2.398, de 21 de dezembro de 1987; prevê medidas voltadas à regularização fundiária de interesse social em imóveis da União; e dá outras providências. Disponível em: <http://www.planalto.gov.br/ccivil_03/_ato2007-2010/2007/Lei/L11481.htm>. Acesso em: 06 jan. 2016. 
UCHOA, Adelaide Maria Rodrigues; RODRIGUES, Francisco Luciano Lima. Alienação de bens imóveis públicos em favor de particulares à luz dos princípios constitucionais da eficiência e economicidade. Revista Eletrônica Direito e Política, Programa de Pós-Graduação Stricto Sensu em Ciência Jurídica da UNIVALI, Itajaí, v.11, n.3, 30 quadrimestre de 2016. Disponível em: www.univali.br/direitoepolitica - ISSN 1980-7791.

Lei no 11.952, de 25 de junho de 2009. Dispõe sobre a regularização fundiária das ocupações incidentes em terras situadas em áreas da União, no âmbito da Amazônia Legal; altera as Leis nos 8.666, de 21 de junho de 1993, e 6.015, de 31 de dezembro de 1973; e dá outras providências. Disponível em: <http://www.planalto.gov.br/ccivil_03/_ato20072010/2009/lei/l11952.htm>. Acesso em: 06 jan. 2016.

Medida Provisória no 2.220, de 4 de setembro de 2001. Dispõe sobre a concessão de uso especial de que trata o $\S 1^{\circ}$ do art. 183 da Constituição, cria o Conselho Nacional de Desenvolvimento Urbano - CNDU e dá outras providências.

Disponível em: http://www.planalto.gov.br/ccivil_03/mpv/2220.htm>. Acesso em: 06 jan. 2016.

FORTALEZA [Município]. Lei Orgânica do Município de Fortaleza. Disponível em:

<http://www.pgj.ce.gov.br/AdmSuperior/assessorias/acc/lom/fortaleza.pdf>. Acesso em: 06 jan. 2016.

TERESINA [Município]. Lei Orgânica do Município de Teresina. Disponível em:

<http://pgm.teresina.pi.gov.br/admin/upload/documentos/77f11ae101.pdf>. Acesso em: 06 jan. 2016.

Submetido em: maio/2016

Aprovado em: junho/2016 